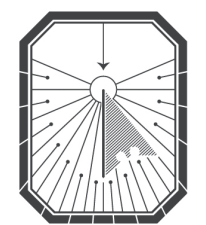

KYIV-MOHYLA

LAW \& POLITICS JOURNAL

KYIV-MOHYLA SCHOLARLY PEER-REVIEWED JOURNALS

The Impact of State-society relations on Anticorruption Agencies in Southern Africa

Author(s): Thato Toeba

Source: Kyiv-Mohyla Law and Politics Journal 5 (2019): 165-192

Published by: National University of Kyiv-Mohyla Academy

http://kmlpj.ukma.edu.ua/ 


\title{
The Impact of State-society relations on Anti- corruption Agencies in Southern Africa
}

\author{
Thato Toeba \\ LLD Candidate, \\ University of the Western Cape, South Africa
}

\begin{abstract}
Corruption remains a fundamental and intricate issue in public administration to date. It is featured constantly as one of the foremost discontents that societies around the globe have with the administration of public service and the resulting socio-economic problems. ${ }^{1}$ While anti-corruption law is extensively adopted in Southern Africa, the implementation of law has encountered deficiencies and challenges in tackling, especially grand corruption. This paper focuses on Anti-Corruption Agencies (ACAs) and their efficacy in controlling corruption in Southern Africa. It argues that the inability of ACAs to arrest corruption in Southern Africa is embedded inter-alia in the precarious state-society relations in the region which perpetuate the ambiguity for corruption and impede the formation of a moral consensus on anti-corruption law. The state, which is regarded generally as a trustworthy custodian of social progress is viewed by most domestic constituents as apathetic to social welfare with its political ambitions as anti-ethical to those of citizens. The paper proposes the analytical framework of Context, Resonance \& Relevance (CRR) to assess the compatibility of Anti-Corruption Agencies (ACAs) in Southern Africa with domestic institutional contexts. In this model, context assesses ACA framework in relation to the domestic political environment and the extent to which it allows ACAs the capacity to function efficiently amidst competing political priorities. Resonance is concerned with the political relationship between the domestic society and the ACA and whether the operating framework sufficiently engages cultural codes specific in said society which De Sardan argues "banalise" or "justify" corruption. Relevance engages typologies of corruption in the region and whether reforms sufficiently are targeted at specific problems.
\end{abstract}

Key Words: state-society relations, Anti-Corruption Agencies, corruption, Southern Africa, anti-corruption law.

\section{唡}

\section{Introduction}

Corruption remains a fundamental and intricate issue in public administration to date. It is featured constantly as one of the foremost discontents that societies around

$1 \quad$ Michael Bratton, and E. Giymah-Boadi, Do Trustworthy Institutions Matter for Development?

Afrobarometer Dispatch No. 112. (2016): 3 . 
the globe have with the administration of public service and the resulting socioeconomic problems. ${ }^{2}$ While anti-corruption law abounds in many countries, the anticorruption discourse in the 2010 s has been focused mainly on the implementation of the law, which has encountered deficiencies and challenges especially in tackling grand (as opposed to petty) corruption.

The paper focuses specifically on the Southern African region because of the shared institutional culture and political and socio-economic history between countries. Further, this southernmost region of the African continent largely adopted whole-sale and uniform anti-corruption law, in the 199os by most countries under donor pressure and conditional lending. The region constitutes the countries of Angola, Botswana, Eswatini (Swaziland), Lesotho, Malawi, Mozambique, Namibia, South Africa, Zambia, and Zimbabwe.

The paper focuses on a central feature of specialized anti-corruption law, being Anti-Corruption Agencies (ACAs) and their efficacy in keeping corruption under control in Southern Africa. Anti-Corruption Agencies are specialized state institutions with the primary purpose of implementing anti-corruption policy through the prevention, prosecution, and investigation of corruption. ${ }^{3}$ ACAs act as liaisons between anticorruption reform which is a creature of international policy and national contexts where such reform is implemented. As illustrated by various studies, most ACAs in Southern Africa do not appear to be sufficiently controlling corruption in the public sector. ${ }^{4}$ The reasons for this inefficacy have been suggested as a lack of conditional prerequisites under which they are projected to succeed, including sufficient resources, independence, and political will. In furtherance, this paper proposes that this inefficacy is rooted in the precarious state-society relations in the region which sustain the ambivalence for corruption and impede a formation of a moral consensus on anticorruption law. ${ }^{5}$

This relationship on which ACAs primarily depend to function is more complex than anti-corruption anticipates. The State, which is generally expected to act as a trustworthy custodian of social progress is viewed by most citizens in Southern Africa as

2 Bratton, Trustworthy Institutions, 3.

3 Jeremy Pope, TI Source Book 2000. Confronting Corruption: The Elements of a National Integrity

System, (Berlin: Transparency International, 2000): 3 .

4 See generally OSISA, Effectiveness of Anti-Corruption Agencies in Southern Africa, (Johannesburg: Open Society Initiative for Southern Africa, 2017); A. Doig "Anti-Corruption Bodies as Discourse-Controlling Instruments: Experiences from South East Europe," in Governments, NGOs and Anti-corruption: The New Integrity Warriors. eds. L. De Sousa, P. Larmour, and B. Hindess (London: Routledge, 2009): 31.

5 P. D. Ocheje, "When Law Fails: A Theory of Self Enforcing Anti-Corruption Legislation in Africa," The Law and Development Review 4, no. 3 (2011): 249; A. Doig, "Good Government and Sustainable Anti-Corruption Strategies: a Role for Independent Anti-Corruption Agencies?” Public Administration and Development 15 (1995): 154. 
apathetic to social welfare and its political ambitions as antithetical to those of citizens. ${ }^{6}$ According to Ocheje, having perpetually relied on violence to assert its authority, the State in Africa fails to sustain its legitimacy as a moral vanguard for appropriate behavior. ${ }^{7}$ Further, its failure to achieve development goals and to judiciously manage the public sector provides no incentive for cultivation of loyalty between itself and citizens. ${ }^{8}$

This paper asks; what is the impact of the relationship between the state and society on the ability of anti-corruption agencies in Southern Africa to investigate, prosecute, and prevent high profile corruption in the public sector? Research on anticorruption in the region is overwhelmingly focused on state actors and their failure to seriously engage corruption. However since implementing anti-corruption law requires the state to orientate the anti-corruption norm locally, the conditions in the domestic environment and how corruption is perceived by society in that environment are crucial to the operation of ACAs.

This piece proposes the analytical framework of Context, Relevance, \& Resonance (CRR), as a tool to assess corruption and anti-corruption mechanisms even in situations where the stated environmental preconditions for effective ACAs are absent. Context assesses the framework of ACAs in relation to domestic political environments. Relevance engages the types of corruption in the region and whether anti-corruption reform is suited to sufficiently target specific problems. Resonance is concerned with the relationship between the ACA and domestic actors (including the government, other institutions and the general public) and the coordination of these relationships. Essentially, CRR analyses the relationship between the ACA and the political culture, the political community as well as the issues of corruption arising in their environment, and deals also with the operational and legal capacity of ACAs to function adequately. ${ }^{9}$ With regards to the state-society relationship, this framework provides the opportunity for the adequate tailoring of ACAs as far as the three elements evaluate the relational patterns between the public and public policy and anticipate anti-corruption mechanisms which are able to function in spite of complexities in this relationship.

The paper is organized in three parts. The first lays down the proposed theoretical framework, the second part explores state-society relations in southern Africa through the elements of CRR and the impact thereof on corruption and the efficacy of ACAs. This theory is illustrated by the case of Lesotho. Finally, the paper concludes by proposing a reorientation of ACAs through citizen centric measures, particularly constitutionalization of ACAs.

6 See A. Mafeje, “The Role of State Capitalism in Predominantly Agrarian Economies.” Science, Ideology and Development, Three essays on Development (Upsala: The Scandinavian Institute of African Studies, 1978), 5, Ocheje, When Law Fails, 249.

$7 \quad$ Ocheje, When Law Fails, 249.

8 Mafeje, State Capitalism, 5 .

9 See T. Christensen, P. Lægreid, and K. Rovik, Organization Theory and the Public Sector Instrument, Culture and Myth (London: Routledge, 2007), 3. 


\section{Theoretical Framework}

CRR is an analytical framework based on organizational theory in the public sector and seeks to analyze the suitability of ACAs to effectively and sustainably address corruption in Southern Africa. Organization theory focuses on the organization of the public sector in representative democracies by emphasizing the link between public organizations and public policy.10 Since "the people who shape public policy normally act on behalf of formal organizations," it is assumed that the affiliations of the organization as well as the environment in which actors in public decision-making operate will "influence their way of thinking and their behavior, and hence the content of public policy." ${ }^{11}$ In terms of Christensen et al:

"An organization theory approach to the public sector assumes that it is impossible to understand the content of public policy and public decision-making without analyzing the way politicaladministrative systems are organized and their modes of operation." ${ }^{12}$

The relationship between the State and people is precisely central to the analysis of public policy (in this instance anti-corruption policy) and its implementation. Organizational theory emphasizes "organizations consisting of people [and] people in an organizational context," thus this relationship offers the necessary context for these interactions in Southern Africa. State-society relations affect anti-corruption policy since the control of corruption is primarily the responsibility of the State exercised with the help of citizens who can identify and report corruption..$^{13}$ Further, this relationship is central to anti-corruption since the charge for corruption; the use of public resources for personal gain, is usually imposed by citizens against the State apparatus, while at the same time those who administer the State are also citizens.

Anti-corruption reform in Southern Africa emerged from the same historical impropriety which this paper argues complicates relations between the State and society, being the regulation of African problems from foreign hegemonies. ${ }^{14}$ The specialized reform is internationally prescribed and elicits compliance in domestic contexts through conditional lending imposed by the international donor community through primarily the World Bank and the IMF. ${ }^{15}$ However, as organizational theory suggests, people within ACAs as well as informal institutions in their external environment will

10 Christensen, Organization Theory, 2.

11 Christensen, Organization Theory, 2.

12 Christensen, Organization Theory, 2.

13 Christensen, Organization Theory, 3.

14 J. McCoy, and H. Heckel, "The Emergence of a Global Anti-corruption Norm" International Politics 38 (2001): 68.

15 McCoy, Emergence, 68; M. Finnemore, and J. Sikkink, International Norms Dynamic and Political Change 52, no. 4 (1998): 889. 
affect how the ACA identifies problems and respond to them. Similarly, the modus operandi of ACAs will be influenced by other formal organizations in the public and private sectors, by civil society organizations, and by international players. ${ }^{16}$

Law has been extensively adopted to capacitate ACAs to fight corruption in Southern Africa, however ACAs have encountered political interference and financial deprivation which limit their ability to operate. ${ }^{17}$ Organizational theory proposes that this is because formal rules do not apply unrestrictedly but encounter informal norms which "evolve and become important for the activities of formal organizations." 18 While anti-corruption assumes that human behavior in corruption is solely calculative, selfserving and concerned only with opportunities for maximum benefit, organizational theory highlights the synergy between rational calculation and institutionalized behavior. ${ }^{19}$ March and Olsen argue that, in the analysis of rules and situations, one carefully observes the process through which rules are rendered into action by constructively interpreting available resources and observing the intermediacy "between rules and purposeful behavior and the factors that enhance or counteract rule-following and mediate the impact rules have on behavior." ${ }^{20}$

The elements of context, resonance, and relevance are proposed as lenses to evaluate the capacity, cohesion, and coordination of international anti-corruption law in the Southern African context and are elaborated below.

\section{Context}

Context in CRR analyses the sustainability of anti-corruption law in a particular environment. Context is defined as "the situation within which something exists or happens and that can help explain it." ${ }^{21}$ In this sense, Context proposes that ACAs be evaluated with adequate cognizance to its environmental situation in order to fully appreciate its capacity to sustainably manage corruption, particularly in key positions of public administration. ${ }^{22}$ In other words, to be effective, at least minimally, the ACA

16 Christensen, Organization Theory, 2.

17 Christensen, Organization Theory, 2.

18 Christensen, Organization Theory, 2; I. Carr, "Corruption, Legal Solutions and Limits of Law" International Journal of Law in Context 3, no. 3 (2007): 239 and Ocheje, When Law Fails, 240.

19 Christensen, Organization Theory, 2.

20 J. March, and J. Olsen, "The Logic of Appropriateness" WP o4/o9 (2009): 8 Centre for European Studies. Accessed June 12, 2019 https://www.sv.uio.no/arena/english/research/publications/ arena-working-papers/2001-2010/2004/wpo4_9.pdf; J. March, and J. Olsen, Democratic Governance. (New York: Free Press, 1995): 30-31.

21 See the Cambridge Dictionary available at http://dictionary.cambridge.org/dictionary/english/ context. on 'Preventing Corruption in Public Administration: Citizen Engagement for Improved 
must be aware of the political and economic environment of the society in which it operates so as to comprehend the dynamics of the corruption it is meant to combat.

Context establishes the capacity of ACAs to understands the nature of its mandate and functions in relation to its local environment. Doig also deals with context, and argues that, generally, in developing countries, "states are institutionally young and inherit bureaucracies that ... lack many of the regulatory institutions that are necessary for a modern state and economy to function." ${ }^{23}$ Thus, it is important to fashion anticorruption strategies around the conditions in which ACAs are established as context is critical in tailoring an ACA that understands the nature of its mandate and functions in relation to its local environment.

\section{Relevance}

Relevance is defined here as "the degree to which something is related or useful to what is happening." ${ }^{24}$ While corruption occurs everywhere globally, it manifests differently in varying contexts. ${ }^{25}$ Relevance suggests that the efficacy of ACAs will depend inter-alia on the accurate diagnosis of corruption in a particular environment. ${ }^{26}$ Quah contends that:

"Those governments which diagnose correctly the causes of corruption and take appropriate measures to minimize, if not eliminate these causes; will be more effective than those governments which do not observe this logic of corruption control." ${ }^{27}$

Relevance thus recognizes that the "best prevention strategies ... are the ones that are best tailored to solve the problem at hand." ${ }^{28}$ According to Shah, programs fail when the type of corruption ACAs are targeting, and the underlying, country-specific

Transparency and Accountability' United Nations, New York, 2012), available on: http://unpanı. un.org/intradoc/groups/public/documents/un-dpadm/unpano49589.pdf:15.

23 A. Doig "Anti-Corruption Bodies as Discourse-Controlling Instruments: Experiences from South East Europe" in Governments, NGOs and Anti-corruption: The New Integrity Warriors eds. L. De Sousa, P. Larmour, and B. Hindess (London: Routledge, 2009): 72.

See Cambridge Online Dictionary available at http://dictionary.cambridge.org/dictionary/ english/relevance.

See Doig, Good Government, 16o; J. S. T. Quah "Comparing Anti-corruption Measures in Asian Countries: Lessons to be Learnt," Asian Review of Public Administration 11, no. 2, (1999): 71; Mills, Causes, 12.

26 Quah, Comparing, 71.

27 Quah, Comparing, 71.

28 A. Gorta, Corruption Prevention: Researching How And Where To Intervene Paper Presented At Empowering Anti-Corruption Agencies: Defying Institutional Failure And Strengthening Preventive And Repressive Capacities ISCTE Lisbon, May 2008, accessed August 10, 2016 http:// 
causes or "drivers" of corruption they are tackling are not properly identified.29 Doig similarly speaks of a need to consider the "workload" of the ACA by identifying the types and levels of corruption and the threat they pose to political administration, public perceptions and democracy. In Southern Africa, political corruption is even harder to control. In Malawi for example, Daka argues that while there have been a number of prosecutions for petty corruption, "there has not been even a single successful prosecution of corruption cases bordering on high-level political corruption" since the establishment of the Malawian Anti-Corruption Bureau. ${ }^{30}$ This exercise of matching problems to solutions, according to Doig, is necessary for the development of strategies and institutional structures appropriate to the "likely volume and type of work the agency will be undertaking." ${ }^{31}$

\section{Resonance}

Under "Resonance," ACAs are analyzed in terms of their relationships to the people, institutions and legal system of the societies they serve. According to Lawal, anticorruption convictions require buy-in from the general public. ${ }^{32}$ The agency should be able to fit into the fabric of the society's governance system and cultural values. This way, it is not isolated from other public institutions and from the general public. This is particularly important because one of the fundamental functions of an ACA is to coordinate different law enforcement agencies responsible for combating corruption. ${ }^{33}$ Ideally, therefore, an ACA must resonate with the greater tapestry of the public administration structure in the society.

Further, a resonant ACA earns the recognition of society insofar as it becomes an extension of existing government structures. ${ }^{34}$ A model ACA created for one country

ancorage-net.transparencia.pt/wp-content/themes/twentyfourteen/assets/documentos/gorta. pdf:5.

29 A. Shah, "Tailoring the Fight against Corruption to Country Circumstances" Chapter 7 in Shah A Performance Accountability and Combating Corruption (Washington D. C.: World Bank, 2013): 230, accessed June 15, 2019 http://www.worldbank.org/en/news/press-release/2013/12/19/ corruption-developing-countries-world-bank-group-president-kim.

30 D. D. Daka, Challenges to the Successful Implementation of Anti-Corruption Measures: The Case of Political Corruption in Malawi. LLM Thesis, University of the Western Cape (2011), accessed June 15, 2019. http://etd.uwc.ac.za/xmlui/bitstream/handle/11394/3275/DAKA_LLM_2013. pdf?sequence $=1: 2$.

31 Doig, Anti-Corruption Bodies, 66.

32 G. Lawal, "Corruption and Development in Africa: Challenges for Political and Economic Change," Humanity \& Social Sciences Journal 2, no. 1 (2007): 2.

33 OECD “Specialised Anti-Corruption Institutions: Review of Models," (2008), accessed June 15, 2019 http://www.oecd.org/corruption/acn/39971975.pdf:11.

34 See M. Bukovansky, "The Hollowness of Anti-Corruption Discourse," Review of International Political Economy 13, no. 2 (2006): 184. 
will be a difficult fit for another, simply because its external origins make it look unreliable and suspicious to the local community, which is unlikely to trust it. Ocheje argues that the moral ambivalence towards corruption in Africa, "deprives the law of the necessary social and political synergy for its effectiveness." 35 Arguing for a process of re-socialization in the fight against corruption, Carr observes that it is important to make the general public aware of the social impact and the consequences of corruption on themselves as well as their communities. ${ }^{36}$ This public awareness, in the light of Ocheje's submissions, must encompass a consensual ideology about and a shared perception of corruption in a given society. ${ }^{37}$

The analyses of ACAs in the anti-corruption literature do not give sufficient attention to informal institutions in the operating environment of ACAs which may inhibit their projected efficacy. State-society relations in Southern Africa illustrate historical conditions from which these informal norms emerge and provide a background view of the circumstances in which ACAs operate, the problems they are addressing and actors they encounter in fulfilling their mandates.

\section{The Relationship between the State and Society in Southern Africa}

The state refers to the political organization in a particular territory. ${ }^{38}$ Its primary role is exercised through state institutions is to provide social services, security and a robust economic environment for the progress of its citizens. ${ }^{39}$ In most countries in Southern Africa, the most important interaction between the state and society then is the acquisition by the latter of a "better life" for the former. ${ }^{40}$ In the region, states since colonization have never been in a position or form to foreground the socio-economic interests of their native societies in the state's economic and political policies. ${ }^{41}$ While the State under colonization was constructed to serve the interests of the "civil society" which consisted fundamentally of European and Europeanized citizens, independence re-introduced the post-colonial state in Southern Africa as a viable tool through which to pursue socio-economic development of all people previously disenfranchised by colonial rule.

Under independence, the state would seize discretionary power over national resources in order to "strengthen the national economy against critical external economies and competition." ${ }^{42}$ Further, the state would care for the welfare of its people

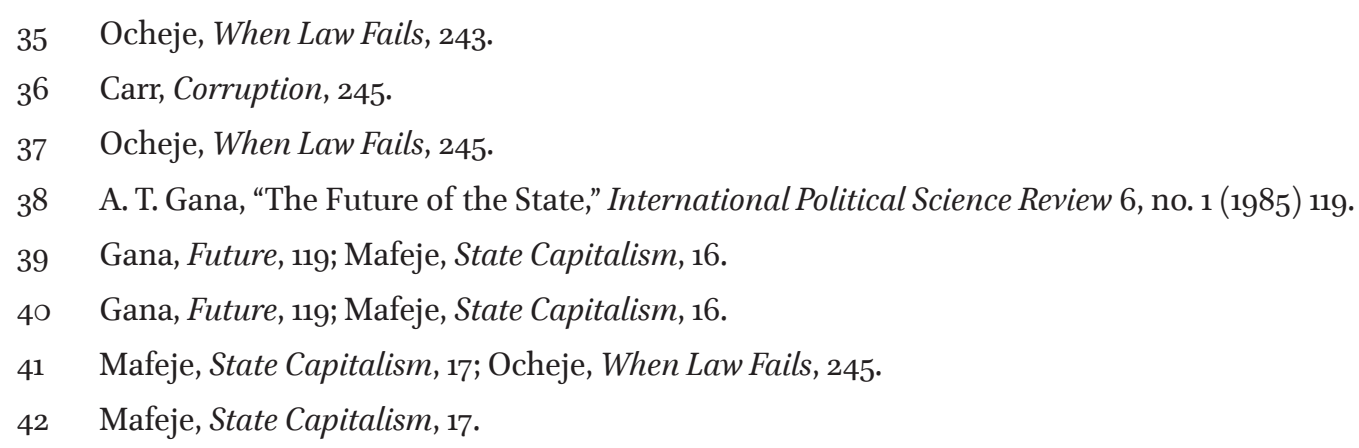


and provide basic services such as health care, education and economic opportunities. ${ }^{43}$ However, since capital after independence remained under the control of colonial and other external agents, post-colonial governments in Southern Africa had no economic power and thus no real financial resources to deliver a mandate of welfare for its people.

To consolidate their economic status, states dabbled in neo-liberalism wherein governments identified "with foreign capitalist interests, while reserving the right to use its newly acquired political power to negotiate for better terms of economic interaction." ${ }^{44}$ For the new States, neo-liberalism implied both their readiness to collaborate with foreign capital for investment as well as a substantial dependence on Western hegemonies for technical and financial support. ${ }^{45}$ Neoliberal policies insinuated further that the new states were not in a position to fully prioritize the socio-economic demands of its citizens because of concessions they would have to make in the course of benefiting from foreign capital.

The attraction of foreign investment has since become a guiding principle in the policies of government, especially those regarding the economy and development. ${ }^{46}$ Structural adjustment Programmes (SAPs) from the IMF provide a poignant example. ${ }^{47}$ According to Bond \& Dor, SAPs required the elimination of barriers to international trade, liberalization of financial markets, currency devaluation, lower corporation tax, fiscal austerity, (targeted particularly at social spending), privatization of state owned corporations, introduction of user fees and the disconnection of services to those who can't pay. 48

The promise of capitalism under SAPs was a thriving economy as a result of an attractive investment climate, development and the general prosperity of society. ${ }^{49}$ These promises, especially in relation to the general public failed to materialize in virtually all countries. Rather, trade barriers raised prices for consumers and placed a tax burden on citizens. The privatization of national companies resulted in losses of jobs while the lack of control over commerce meant that those who worked in multinational corporations did so under oppressive labor environments. ${ }^{50}$ Further, local businesses were basically swallowed by international corporations which have the

Mafeje, State Capitalism, 17 .

Mafeje, State Capitalism, 17.

Mafeje, State Capitalism, 17 .

J. Stiglitz, Globalization and Its Discontents. (London: Penguin Books, 2002): 18.

F. Heidhues, and G. Obare, "Lessons from Structural Adjustment Programs and their effects in Africa" Quarterly Journal of International Agriculture 50 (2011): 57; T. Polzer, "Corruption: Deconstructing the World Bank Discourse," Working Paper Series, Development Studies Institute no. $01-18$ (2001): 14 .

P. Bond, G. Dor, "Neoliberalism and Poverty Reduction Strategies in Africa. Discussion paper," Regional Network for Equity in Health in Southern Africa (2003): 2.

Stiglitz, Globalization, 19 and Polzer, Corruption, 14.

Stiglitz, Globalization, 19. 
best odds at competing in global markets because of their capital base. ${ }^{51}$ This systematic alienation of people from the economic and social benefits expected to accrue from the state has established and is sustaining the precariousness of the interactions between the state and society in Southern Africa. ${ }^{52}$

In anti-corruption, the paper makes three arguments in line with "context," "relevance," and "resonance" in the CRR framework. First, it argues under context that the state in Southern Africa is inherently corrupt and not in a position to seriously and genuinely address corruption. Secondly, this section argues that the law on ACAs is not necessarily "outfitted" or aligned to fit conceptualizations and perceptions of corruption in Southern Africa. Lastly, it is argued in terms of resonance that the state in many countries in Southern Africa provide no incentive for cultivation of loyalty between itself and citizens. The three arguments are elaborated below.

\section{The Capacity of States to Effectively Address Corruption in Southern Africa (Context)}

As already illustrated, "context" emphasizes the active consideration of the environment in which ACAs operate as influenced by various factors, particularly the economic and political conditions in these environments. It is essential to the analysis of the capacity of ACAs to fulfill its functions. In terms of UNCAC, this capacity is constituted by whether there is sufficient independence and resources for the ability of ACAs to function effectively and without political intrusion. ${ }^{53}$

\section{Independence}

The requisite for independence is based on the position of ACAs as accountability institutions against encroachment of power in public administration. ${ }^{54}$ ACAs typically engage allegations of violations of trust between the public and the state. Particularly in grand corruption cases, where actors wield substantial authority over the administration of the State, independence suggests that ACAs must be able to still operate without the threat of crippling political intrusion. ${ }^{55}$ According to Meagher, it is insufficient to merely codify independence of ACAs in law without substantively establishing de-facto independence as is the case with most ACAs in Southern Africa. ${ }^{56}$ De facto independence is defined in the South African case of Glenisterv The President of the Republic of South Africa \& Ors as reliant on whether a "reasonably informed and

$51 \quad$ Heidhues, Lessons, 6 o.

52 See Mafeje, State Capitalism, 17; Gana, Future, 125.

53 Articles $6(2)$ and 36 of UNCAC.

$54 \operatorname{OECD}(2008): 24$.

55 OECD (2008): 24 .

56 P. Meagher, "Anti-Corruption Agencies: A Review of Experience," Journal of Economic Policy

Reform 8, no. 1: 4 . 
reasonable member of the public will have confidence in the entity's autonomy." ${ }^{57}$ Thus, as Moseneke \& Cameron held, independence is constitutive of public confidence in the autonomy of an ACA. ${ }^{58}$

\section{Finances and Resources}

The requisite for resources on the other side is affected both by the economic and the political capacity of a particular context. ${ }^{59}$ In Southern Africa, particularly where ACAs have central anti-corruption mandates, a lot of resources are required to institute investigations, train staff, employ specialists, conduct public outreaches, and most importantly enumerate employees of the ACA such that corruption does not become attractive to them. ${ }^{60}$ As the OECD observes, financially endowed ACAs strengthen the confidence the public has in the ability of ACAs to control corruption. ${ }^{61}$ At the same, perceived failure of ACAs while millions of much needed resources are poured into the agency every year also weakens public confidence since ACAs appear wasteful. In this instance, the costs of maintaining the ACA is hardly justifiable from a local perspective when other socio-economic issues seen as a priority over anti-corruption are neglected. ${ }^{62}$ Furthermore, those governments which do not seriously want corruption controlled can intentionally starve ACAs of resources in order to weaken their capacity to function. Here, the issue concerned is the authority of the executive to determine the budget of the ACA without any substantial input from parliament. ${ }^{63}$ Once again, since anti-corruption is mainly concerned with corruption in these same entities, the risk of political intrusion through resource starvation is a real cause for concern.

\section{The "Context" of ACAs in Southern Africa}

The blueprint for ACAs in Southern Africa most countries came from Hong Kong's ICAC including in Botswana through the Directorate for Corruption and Economic Crimes (DCEC), Eswatini by the Anti-Corruption Commission (ACC), Lesotho through the Directorate for Corruption and Economic Offences (DCEO) Malawi in terms of the Anti-Corruption Bureau (ACB) ${ }^{64}$ ICAC is placed under the authority of the Chief Executive who has the power to appoint and remove commissioners and the agency is

57 Glenister $v$ The President of RSA \& Ors (2011):108.

58 Glenister $v$ The President of RSA \& Ors.

$59 \operatorname{OECD}(2008): 27$.

60 A. Doig, D. Watt, and R. Williams, Measuring 'Success' in Five African Anti-Corruption Commissions: The cases of Ghana, Malawi, Tanzania, Uganda \& Zambia. U 4 Publication, Bergen (2005): 30 .

$61 \quad$ OECD (2008): 27 .

62 Doig, Measuring, 3 ०.

63 Doig, Measuring, 30; OECD (2008): 28.

64 See generally OSISA. 
financed from Hong Kong's "general revenue." ACAs under donor recommendations in Southern Africa took their structural cue from ICAC and are also placed under the fiscal and administrative authority of the executive.

The context in Hong Kong wherein ICAC became successful however is significantly different from the operating context of ACAs in Southern African countries. ${ }^{65}$ In Hong Kong, ICAC was established in a semi-authoritarian political environment which gives the Hong Kong government a certain degree of control over the state and society and has less requirement of accountability required typically of the more "democratic" governments in Southern Africa. ${ }^{66}$ This factor allowed a committed government in Hong Kong to exercise unfettered discretion on the financial capacitation of ICAC without the pressure of any dissent from opposition as is usually the case with democratic governments. Similarly, a government which is ambivalent on corruption issues, let alone one which the public regards as corrupt can exercise this discretion to derail the capacitation of its ACA. ${ }^{67}$

Even though post-colonial governments in Southern Africa are democratic (in the basic sense of periodic elections), most ACAs adopted in the region are authoritarian in that they are not placed within existing systems (e. g constitutions) of accountability in a democracy. From both the administrative and financial capacity, these ACAs appear vulnerable to political interference in the eyes of society. ${ }^{68}$

Moreover, while societies in authoritarian states, such as Hong Kong, submit to the will of government, governments in democracies are supposed to submit to the will, or at least expectations, of the people. ${ }^{69}$ The Priorities for public spending in a democracy are not determined by the government alone, but include also views of the public. The donor community has prioritized corruption as a barrier for progress in Southern Africa and imposed upon countries the financial responsibility to establish and maintain ACAs. However, as Bratton and Boadi observe, local societies in 36 African countries regard corruption as the least immediate important problem they face..$^{70}$ Other socioeconomic problems including unemployment, health care, education, water supply, poverty, infrastructure, food security, crime and management of the economy are seen as priorities to which governments must urgently attend..$^{71}$ This suggests that there are competing priorities in development on which societies expect public resources to be spent. As a result, ACAs do not always have solid support from the public to lobby their financial backing.

65 I. Scott, "The Challenge of Preserving Hong Kong's Successful Anti-Corruption System," Asian Education and Development Studies 6, no. 3 (2017): 228; Doig, Measuring, 35.

66 Scott, Challenge, 228.

67 See OECD (2008): 24.

68 Doig, Measuring, 31; W. De Maria, "Cross Cultural Trespass: Assessing African Anti-Corruption Capacity," International Journal of Cross Cultural Management 8, no. 3 (2008): 318.

69 Bratton, Trustworthy Institutions, 11.

70 Bratton, Trustworthy Institutions, 11.

71 Bratton, Trustworthy Institutions, 11. 
For context, the relationship between the state and society is crucial because the state against whom corruption charges are usually leveraged is in control of anticorruption efforts. As illustrated earlier, this relationship has evolved to position the state as inherently corrupt and not in a position to seriously and genuinely address corruption. Since capacity depends largely on the perception of the public, that is whether ACAs are independent enough to fight corruption and whether they are endowed with, or should be endowed with financial resources requisite for their operations, the precarious relationship between the state and society suggests that ACAs in their current from have no substantial capacity to fight corruption.

\section{Concepts of Corruption and Anti-Corruption in Southern Africa (Relevance)}

In CRR, "relevance" evaluates conceptions of corruption from domestic views, and analyses the extent to which the generalized foundation of ACAs target these problems. ${ }^{72}$ As Quah argues, corruption is defined by a practical and accurate diagnosis of its perceived causes in different contexts. ${ }^{73}$ While the nature of corruption and its causes vary contextually, the universal conception of corruption is not necessarily replicated in domestic situations. ${ }^{74}$ Relevance proposes that anti-corruption remedies, in this case ACAs should reflect nuances in conception of corruption as defined by context. In Southern Africa, the opportunity to properly make this diagnosis and to account for the nuances of corruption before ACAs were adopted was completely missed. ${ }^{75}$ ACAs were adopted rather as a condition of financial aid by the international donor community (consisting of the Brettonwood institutions, donor countries and international nongovernmental organizations). ${ }^{76}$ Compliance in domestic jurisdictions was secured as De Sousa argues by the reliance of most countries on this donor community for financial and technical aid. ${ }^{77}$ The evaluation of relevance is carried out by analyzing the concept of corruption from the international perspective and assessing its applicability in the Southern African context, particularly in relation to state-society and relations.

\section{Corruption and Anti-Corruption under International Law}

Anti-corruption reform takes a capitalist approach to corruption in terms of rational choice theory which explains corruption as state monopoly and the exercise of the discretionary powers of government without adequate accountability $(\mathrm{C}=\mathrm{M}+\mathrm{D}-\mathrm{A}) .{ }^{78}$

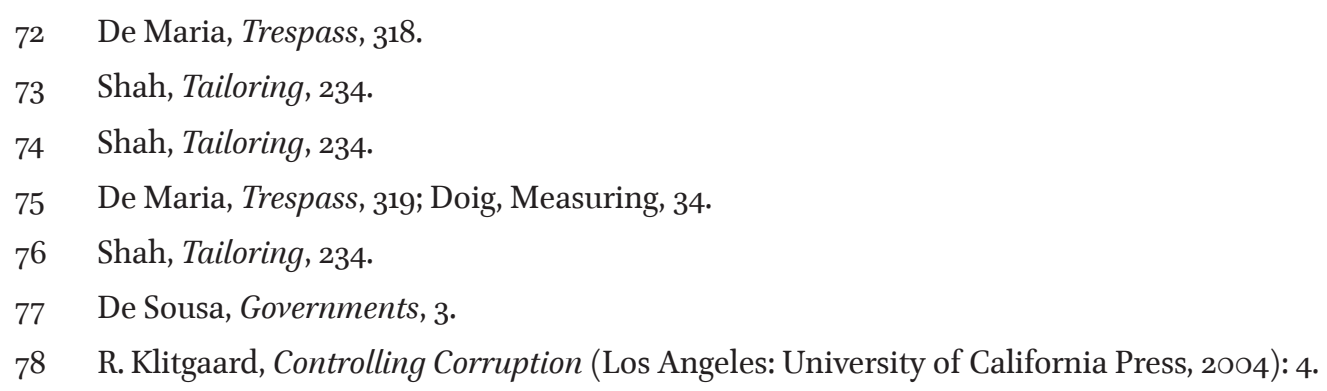


Corruption is understood to emerge from the restriction of global market from participating freely in local economies. ${ }^{79}$ According to the World Bank, corruption stagnates development, causing government intervention where unnecessary (for example, participating in the economy) and frustrating the process of implementing policies in situations which do require government action (for example, providing social services). ${ }^{80}$ The Bank proposes that:

"The opportunity for corruption is a function of the size of the rents under a public official's control, the discretion that official has in allocating those rents, and the accountability that official faces for his or her decisions." ${ }^{81}$

Corruption is thus seen as a barrier to development since it aggravates the risk of "a country being marginalized in the international economy in order to attract foreign investment which funds development goals." 82 The purpose of anti-corruption reform is therefore to liberalize domestic economies in order to create a conducive environment for the maintenance of investor confidence. ${ }^{83}$

Functions of ACAs to prevent and repress corruption flow from these conceptions of the issue. In the first instance, ACAs guard against the monopoly of the state by promoting the participation of society, pursuing principles of "good governance" and overseeing public education on anti-corruption. In the second instance, ACAs repress corruption through law enforcement by investigating and prosecuting "abuse of power" in the public sector. ${ }^{84}$

\section{The "Relevance" of ACAs under State-Society Relations in Southern Africa}

In Southern Africa, corruption features significantly as a symptom of the failure of government to perform its role as well as a means to survive its fecklessness. ${ }^{85}$ Under the oppressive colonial regime, the corruptness of the state appeared in its separatist and exploitative policies. ${ }^{86}$ Colonization was entrenched through the "divide and rule" strategy which separated opponents of the colonial state from supporters by violently repressing the latter and rewarding the former with economic benefits like land, and

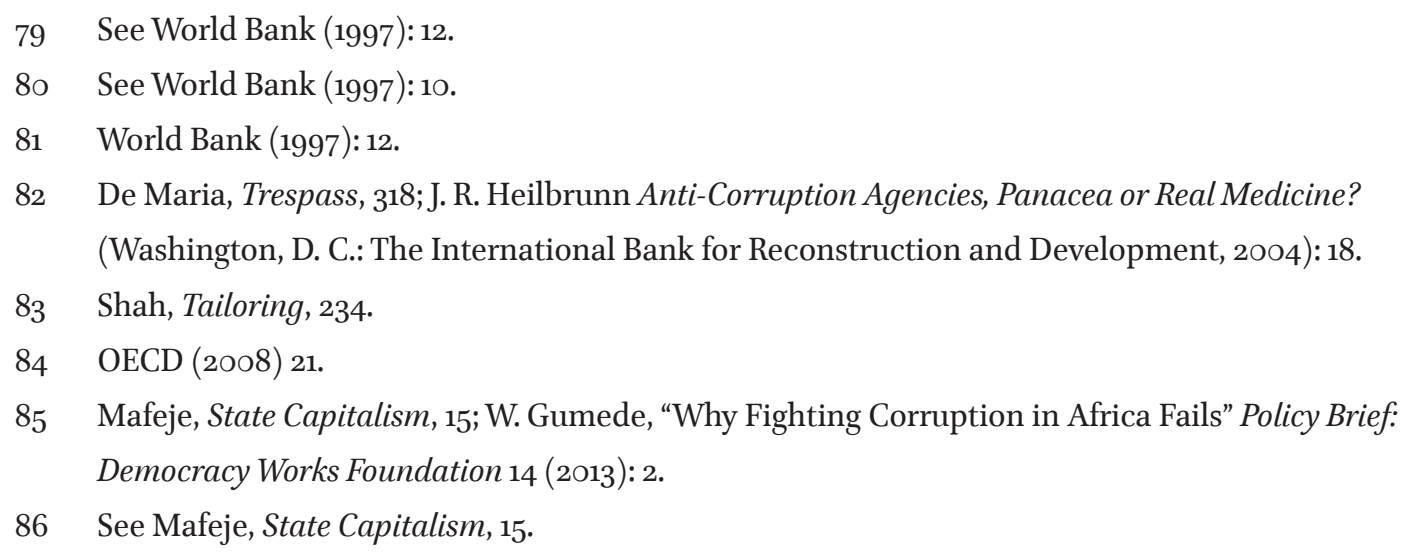


social mobility in the form of positions of authority. The incentives to compradors of the state constituted corruption since traditional leaders in the pre-colonial society were derailed from the service of people as was customary to serving their own interests while aiding the colonial state to expand its authority. ${ }^{87}$

In the capitalist state, collaborations between the government and capital provided a fertile ground for the looting of public institutions by the ruling elite who had come to replace the capitalist class under colonization. ${ }^{88}$ Corruption soared as government leaders scrambled to accumulate wealth through the state while at the same time offering the fate of its citizens to international corporate interests. ${ }^{89}$ These collaborations between the state and capital from the perspective of citizens, is constitutive of corruption since it prioritises capital and provide government officials with a safe enclave for corruption. ${ }^{90}$ Corruption is not just a white collar crime, but embodies the diminishing trust society has in state institutions as a result of their perceived failure to use states' resources for the benefit of the public.

Even though the proliferation of ACAs in Southern Africa coincided with growing demands for functional states which pursue social and economic security for its citizens as expected at the end of colonialism, the establishment of anti-corruption ACAs in the region did not flow from a contextual diagnosis of the nature of corruption therein. ${ }^{91}$ Concepts of corruption from the international perspective positioned corruption in Africa as a hallmark of "bad governance," while the perception of citizens also presented governance in the region as bad. Thus, international donors converge with domestic perceptions on the corruptness of the state in Africa, but differ significantly on the theories for these conclusions. Capitalism regards anti-corruption as contingent on deregulation, and the creation of a conducive environment for competition and the free market economy, however, the role of the state in Africa after independence is measured on nationalist ideas and the very idea of state control. In Southern Africa, core social problems which lend the state the appearance of being corrupt from local imaginations as argued below flow from its failure to take control of public resources, not necessarily its monopoly of markets. ACAs in this regard appear irrelevant as far as they prescribe anti-corruption law without engaging situations and conditions which give rise to opportunities for corruption.

\section{Anti-Corruption in Relation to Affiliations (Resonance)}

Under "resonance," ACAs are analyzed in terms of their affiliations to actors in anti-corruption including the general public who detect corruption, affiliated state institutions like the national police force, the prosecution authority and the judiciary

\footnotetext{
87 Ocheje, When Law Fails, 241.

88 Mafeje, State Capitalism, 19.

89 Mafeje, State Capitalism, 19.

90 Ocheje, When Law Fails, 246.

91 De Maria, Trespass, 318.
} 
who support the ACA in investigating and prosecuting corruption. Resonance is based on the position of ACAs as the "overseer" and "coordinator" of domestic anti-corruption mechanisms according to UNCAC. ${ }^{92}$ Further, this element is important because ACAs are anticipated as forums for the dissemination of anti-corruption knowledge. ${ }^{93}$ Since the discharge of functions in ACAs rely on the participation and support of societies, and the broader political organization in their operating environment, they require social cohesion with relevant stake-holders to be effective.

\section{The "Resonance" of ACAs in Southern Africa}

Rising public outcry against corruption on one hand and the reluctance of the public on the other, to empathize with anti-corruption, particularly ACAs to remedy these discontents suggests not that citizens do not care about corruption but that current mechanisms are not sufficiently resonant. ${ }^{94}$

In state-society relations, the colonial project as argued altered the view of the state from national perspectives. Under colonial rule, a dual organization of the State was formed such that two means of power under a single hegemonic authority existed..$^{95}$ "Modern" authority "spoke the language of civil society and civil rights" and claimed to protect the rights of the Europeanized society while the "primordial" authority spoke to community and culture and was concerned with enforcing local traditions. ${ }^{96}$ According to Ocheje, the organization of the state under colonialism created an isolation between societies under civil authority and the primordial society resulting in a general ambivalence from the former in issues of governance. ${ }^{97}$ This duality of publics in Africa provide a reservoir for ambiguity in corruption crimes because of anti-corruption law as argued earlier in the paper. ${ }^{98}$ Conflicting views of morality embedded in this duality and perpetuated by the growing isolation of people from state welfare allow for the dismissal of corruption on the basis of divergent ideas of morality.99 According to Ocheje, divergent views of morality regarding corruption breed mistrust between society and the state complicates anti-corruption efforts because society is unable to reach consensus about corruption, leaving room for public officials to contravene anticorruption law with impunity. Further, these divergent views suggest that even if an official wishes to comply with anti-corruption law, there are no incentives to compel them since they view others actors "equivocal in their commitment to the law." 100

Article 5 of UNCAC.

Lawal, Corruption, 2.

Ocheje When Law Fails, 265.

See P. Ekeh, "Colonialism and the Two Publics in Africa: A Theoretical Statement," Comparative Studies in Society and History 17, no. 1 (1975): 92; Ocheje, When Law Fails, 241.

Ekeh, Colonialism, 92.

Ocheje, When Law Fails, 247.

See Ocheje, When Law Fails, 266.

Ocheje, When Law Fails, 266.

Ocheje, When Law Fails, 254 
Moreover, the duality of publics in Southern Africa has impeded any clear delineations between the public and private, a central feature of anti-corruption. De Sardan contends that the region is characterized by a scarcity of "an ethic of public service", which is attributable to the relative novelty of African societies and the foreignness of their mechanics of governance.

In Southern Africa, post-colonial governments which originally had sought to dismantle class formations came to their "ultimate contradiction" through their encounter with capitalism, contributing to existing contentions between classes. States in the process were further alienated from society which stood disenfranchised by the market system and lost its founding role as the resolution to class struggles. Mafeje argues then the state in this regard became "an instrument of class oppression" and lost its power to "pressure from below." In his view, this impacts development efforts because "there cannot be development without the support and effective participation of the vast mass of the people." 101 Similarly, Ekeh argues that the post-independence state in its "increasing fecklessness," that is its continuous failure to attend to its citizens "neither inspires the ordinary citizen nor endears the state to the populace."102 Through its encounter with the general society, the State has mainly fueled "anger and disgust rather than gratitude and affection." ${ }^{103}$

The emphasis on the essentialism of foreign investment and its indispensable value for economic development in Africa, reveals foreign investment as its primary benefactor. Interests of local societies are made ancillary to the survival and profitability of capital. Thus, the social welfare of communities in domestic contexts appears secondary to the foreign priorities of anti-corruption projects. ${ }^{104}$ De Maria argues that under this policy agenda, "corruption is targeted, not so much for the injustices it extracts from ordinary people, but for the structural problems it could cause private investment." ${ }^{105}$

This year, virtually every country in Southern Africa has experienced citizen protests against the state and the continued alienation of its populace from the benefits of domestic wealth. In these protests, corruption is the foremost subject. ${ }^{106}$ At the same time, there is a growing consensus that domestic problems can no longer be resolved through external agents. ${ }^{107}$ Anti-corruption law, and by extension ACAs, represent this outsideness. While sentiments on the corrosiveness of corruption are shared universally, the remedying theory falls short of empathy because it imagines the development of national economies as dependent on the profits of foreign investment,

\footnotetext{
101 Mafeje, State Capitalism, 17.

102 See Ekeh, Colinialism, 66.

103 Ekeh, Colonisalism, 66.

104 See Bukovansky, Hollowness, 21; De Maria, Trespass, 6.

105 De Maria, Trespass, 8.

106 See M. Monyake, and D. Hough, "Citizens, Bribery and the Propensity to Protest,"

Commonwealth \& Comparative Politics 57, no. 3 (2019): 3 .

107 Ocheje, When Law Fails, 243.
} 
through free-market enterprise. ${ }^{108}$ However, for "third" world countries, there is no real opportunity to equally compete in this enterprise, and this for citizens rings like perpetual subjugation. ${ }^{109}$

CRR emphasizes a pragmatic consideration of an ACA's operating environment as influenced by various factors including the economy and politics of the domestic jurisdiction. Under "context" The evolution of the relationship between the state and society defines this "context" and provides insight on the capacity of ACAs in Southern Africa to prevent, investigate and prosecute corruption. Further, CRR foregrounds the suitability of ACAs in this context by exploring the "capitalist" concepts of corruption as universally prescribed and the view of the problem from in domestic contexts. In terms of 'relevance', the "corruptness" of the state seen from the perspective of citizens as its continued failure to act in the interests of the public contradicts the intentions of anti-corruption law which positions corruption as the monopoly or control of the state in economic activities. In Southern Africa, people demand the state to be more, and not less involved in the control of state resources and the operation of the economy. Lastly, the CRR framework observes domestic affiliations of ACAs in domestic jurisdictions. The element of 'resonance' in this regard foregrounds the relationships anticipated for ACAs with its own internal staff, the general public, other government agencies and the private sector. Anti-corruption reform having been externally formulated need comprehension and empathy from the general society to be effectively applied in domestic contexts. ${ }^{110}$ In "Resonance" it is argued that continuing collaborations between the state and foreign capital, and the prioritization of this capital in anti-corruption entrenches ambivalence for ACAs since law appears to favor foreign interests over those which are domestic and public support cannot therefore be assumed to exist.

\section{CRR in the DCEO in Lesotho}

To illustrate the analysis of CRR in a practical situation, the paper turns to Lesotho as a country example. Lesotho is relevant because it has witnessed in recent years growing tensions between the state and society perpetuated by the perceived inexpediency of the latter to achieve national progress. ${ }^{111}$ In the past decade, the country has held elections three times in what should have been two rounds of elections, with a fourth a constant looming threat under Thabane's current coalition government. ${ }^{112}$ This era of "snap"

\footnotetext{
108 Ocheje, When Law Fails, 243.

109 Mafeje, State Capitalism, 17.

110 Ocheje, When Law Fails.

111 See generally M. Thabane, “Towards an Identification of Historical Roots of Lesotho's Political Instability," Towards an Anatomy of Persistent Political Instability in Lesotho 1966-2016 (Roma: National University of Lesotho, 2017): 1-22.

112 T. Mothibe, "Political Parties and Political Instability in Lesotho". in Towards an Anatomy of Persistent Political Instability in Lesotho 1966-2016, ed. M. Thabane, (Roma: National University of Lesotho, 2017): 48.
} 
elections, usually instigated by proposed parliamentary motions of no-confidence in incumbent prime ministers, has presented a fresh perspective on the precariousness of state-society engagements in Southern Africa. ${ }^{113}$ Coupled with recurring civil protests linked to the failure of the government to perform basic functions like paying salaries of public servants, funding education and health care, corruption and abuses of human rights, the perceived neglect of the government in Lesotho to pursue socio-economic progress has pushed to the forefront the narrative of the state as inherently corrupt.

\section{"Context" in Lesotho}

Lesotho was colonized under Britain from 1868 to 1966 . The state function in the country as an instrument of control to maintain law and order extract economic resources. State institutions which remain unchanged from colonial orientation do not necessarily embody the ethos of democracy, good governance and the rule of law. Independence under the nationalist Basotho National Party (BNP) ushered in a new hope for the re-orientation of the state as a means for social and economic cohesion and progress. However, the turn to neo-liberalist policies in development and subsequent acceptance of structural adjustment programmes derailed this aspiration and entrenched the state closer to imperial interests and further from citizens. ${ }^{114}$ Under SAPs it undertook to mitigate concerns expressed by the IMF, including the need to reduce the size of its civil service, removing subsidies to the country's parastatals, which it is argued drains the national budget as well as managing excessive borrowing and high external loans. ${ }^{115}$ Neo-liberal policies in the country have not yielded reduction of poverty, creation of jobs nor a robust economy. Rather, the perception of the state and its position to develop the socio-economic conditions for citizens remains precarious. ${ }^{116}$ According to Malephane, trust from the perception of citizens in most government institutions has declined from 2012 levels, while perceptions of corruption in state institutions have increased.117

The operating agency in Lesotho, the DCEO as in many other countries in the region is structurally modelled on ICAC, and carries the same three-pronged mandate to prevent, investigate and prosecute corruption. The Directorate remains under the authority of the Prime Minister as far as this office has the power to appoint and dismiss directors. The office of the Director of the DCEO has been a significant political

113 H. "Nyane "The Advent of Coalition Political and the Crisis of Constitutionalism in Lesotho" in Towards an Anatomy of Persistent Political Instability in Lesotho 1966-2016, ed. M. Thabane (Roma: National University of Lesotho, 80).

114 Heidhues, Lessons, 58.

115 B. Setai, "Structural Adjustment Program in Lesotho," Africa Development / Afrique et Développement 16, no. 1 (1991) 7.

116 L. Malephane, "Election Fatigue? Half of Basotho want a Different Way to Choose Leaders, “ Afrobarometer Dispatch 309 (2019): 2.

117 Malephane, Election, 2. 
phenomenon in the frequent contests for power in Lesotho since the attempted coup of August 2014 which marked the beginning of a new and turbulent chapter between the state and citizens. ${ }^{118}$ The independence of the DCEO is precariously viewed by the public and the belief that the agency serves political rather than social interests is firmly held. ${ }^{119}$ Recently, Tom Thabane, the country's premier, placed the incumbent DCEO boss on forced leave pending termination of his contract amidst speculation that the former intended to investigate fraud in the Lesotho Post Bank involving officials of government.

The inefficacy of DCEO usually is attributed to lack of independence, resources and political will cause its inefficacy. Thus the strengthening of these factors in the country is almost always suggested for success. However, by observing the political conditions in Lesotho through the state-society relations, it is clear that the achievement for a "conducive environment" for the operation of the DCEO are far out of reach. The analysis of CRR in this regard, provides a realistic assessment of the DCEO's potential to function effectively. "Context" recognizes that the political situation in the country is not conducive for an anti-corruption agency to be administered under the executive arm of government as it is seen as corrupt.

\section{Relevance in Lesotho}

In Lesotho, concepts of corruption as defined by anti-corruption law are not always concomitant to domestic perceptions of corruption. Corruption is regarded by most citizens as the epicenter of all political and social problems in Lesotho. ${ }^{120}$ Like many of its counterpart, Lesotho unquestionably adopted anti-corruption reform as per donor recommendations to qualify for financial assistance. Anti-corruption law is therefore framed in rational choice terms, and aims to limit the discretion of public officials in the exercise of public authority.

In the country, this view was expressed in two policies adopted by the government in the past year. The first relates to the decision of the government to legalize the growing of cannabis "marijuana" for medical purposes. While most citizens were hopeful that this policy presented an opportunity to exploit the lucrative opportunity (the cannabis industry is projected at US $\$ 55,8$ billion by 2025 ), the government priced cannabis licenses at $\mathrm{M}_{5}$ millions (\$341,948.14). It goes without saying that this price immediately sidelines local constituents who can never access this money. In particular, the fact that growing cannabis in Lesotho is still generally criminal suggests that foreign companies who have a historical advantage over global trade are permitted to profit from cannabis when citizens do not. ${ }^{121}$ This policy seen as the continued collusion

118 Mothibe, Political Parties, 49.

119 L. Machobane, “A Microscopic View into Lesotho's Forty Year Period of Independence:1966-2006" (2006), accessed July 15, 2019 http://unpan1.un.org/intradoc/groups/ public/documents/aapam/unpano25648.pdf.:11.

120 See Malephane, Election, 2.

121 Sunday Express, (March 2019) accessed December 26, 2019 https://sundayexpress.co.ls/multimillion-maloti-licence-fee-to-grow-marijuana/. 
between the state and capital to further disenfranchise citizens entrench the view of the state as corrupt.

Another policy which reveals the corruptness of the state in Lesotho is the wool and mohair. Following the entry into a monopoly deal between the Lesotho government and a Chinese broker, Stone Shi, Lesotho passed the Wool and Mohair Licensing (Amendment) Regulations, 2018 which bound some 30,000 farmers who rely on exports of wool to South Africa in the country to only export wool through the Chinese investor's from export mohair without Shi's shearing centre. The incumbent Prime Minister Thabane even appealed to the policy to arrest those who failed to comply with the regulations. Though the regulations have been repealed as a result of mounting citizen pressure, this collusion between the government and Shi express the cosy relationship government officials usually enjoy with foreign capital at the expense of people. According to Ntaote, affected farmers were selling their produce as a far lesser price than before and the payments were grossly late. ${ }^{122}$ The state in this case acted as an instrument of exploitation against citizens. Whether or not the deal the government concluded with Shi followed proper bureaucratic channels, the fact that the state which is expected to champion social and economic progress acted contrarily, that is in concert with capital to repress and cheat people out of their livelihoods, is seen as corruption. ${ }^{123}$

Conceptualizations of corruption in anti-corruption as reflected in the PCEO Act are not entirely coherent with social perceptions of the corruptness of the state in the country. Only the monopoly of political power is arraigned while the economically powerful can monopolize industries unabated. While government monopoly impact international trade, capital monopoly as illustrated by the incidents above disenfranchises ordinary citizens. The element of "Relevance" under CRR reveals fundamental contradictions inherent in anti-corruption law wherein the same ideology (foreign interventions) which creates the DCEO also renders the state as corrupt from the perception of the public.

\section{Resonance in Lesotho}

Since, there has been no real effort to consolidate anti-corruption law with the lived experiences of corruption as it occurs in the Lesotho, informal institutions which inform the decision-making process is public administration remain unaccounted for.

While being governed through a "modern" system, culture and traditional rules still regulate matters in the nation which is most concentrated in rural areas. ${ }^{124}$ Many people recognize and participate in the culture of gift giving for example. It is not

122 Centre for Investigative Journalism (July 2019) accessed December 26, 2019 https://lescij. org/2019/07/o3/how-wool-and-mohair-farmers-were-tossed-into-poverty/.

123 Malephane, Election, 11.

124 S. Poulter, Legal Dualism in Lesotho: A study of the Choice of Law question in Family Matters. (Morija Morija Sesuto Book Depot, 1981): 2. 
unusual for good service to be rewarded with gifts, or to encourage favorable service in the future through the giving of gifts. Today, "gift-giving" has assumed a contour of corruption as it resembles rampant bribery in the public sector, and presents dilemmas in the delineation between traditional gift giving and the crime of bribery. ${ }^{125}$ Thus the DCEO is constantly challenged by competing informal institutions which compete with the mandate of the DCEO.

Further, it is culturally and generally recognized that "khomo e polang ha e tlanngo emolomo," literally translated "cattle employed to thrash corn should not have its mouth tied." In other words, such cattle can eat as it ploughs. Of course, in anti-corruption, this belief appears as abuse of powers. In Lesotho, Mekenye observes that this practice emerged because:

"The chiefs were the caretakers of the land and the nation on behalf of the people. And, the chiefs were worthy of their positions only if they remained responsive to the people's needs, hence the saying that morena ke morena ka batho (a chief is a chief by the people)."

For Basotho who traditionally recognize the authority of chiefs and the monarchy in administering communal property, the idea of eating while trashing corn" is only a privilege of being in such authority. It is therefore not shocking, let alone criminal for a leader to, in the dispensation of his duties occasionally use communal resources for personal use.

The element of "resonance" is fundamental and also identified as a missing link in anti-corruption, as citizens in Lesotho show little affinity towards ACAs. According to Kapa, the DCEO has between 1999 and 2012 submitted 37 cases for prosecution out of with 2 convictions while in 2012, it brought 71 cases before the courts, resulting in 16 convictions and two acquittals. While there may be other reasons for these low statistics, it is clear that public access to the DCEO is currently scarce. Under resonance it is argued that this is because in Lesotho, society is more affiliated with informal institutions. ${ }^{126}$ In Lesotho, the public has expressed more trust in the King, religious leaders and traditional leaders than in most apparatus of the state. ${ }^{127}$

\section{Conclusion}

The CRR approach is essential to understanding the politics in the working environment of ACAs. Where CRR is the underlying rationale, mainstream requirements assume a meaning and structure that is comprehensible to all key participants in the institution. The public, as well as other institutions, will be able to understand the ACA as a complementary structure within the existing public administration system. Further,

125 Machobane, View, 11.

126 Malephane, Election, 2.

127 Malephane, Election, 2. 
the approach harmonizes the contentious issues in ACA discourse of donor ACAs and the incentive of foreign aid, on the one hand, and local moral ideologies, on the other. Donor funding of institutions is crucial for the development of economies and empowerment of people. However, for ACAs to resonate with local communities, the conditions attached to aid must be cognizant of the environment in which such aid is deployed. The CRR approach will facilitate the identification of the special context in which subsequent requisites, such as independence, can be achieved maximally. Practically, a CRR approach can be achieved through existing democratic processes in different countries, including constitutionalization briefly discussed below.

The function of constitutionalism is to check the abuse of power and the misuse of State resources through accountability, the rule of law and the separation of powers. ${ }^{128}$ Constitutions in many countries in Africa adhere to constitutional authority and its supremacy as the highest political arbiter. Hence, the establishment and authority of accountability institutions similar to ACAs such as the Ombudsmen, Directors of Public Prosecution and Attorneys-General is guaranteed usually under constitutions. ${ }^{129}$ Constitutions govern appointments and removals of key offices in these entities, procedures for their accountability and autonomy as well as processes for obtaining necessary resources for their maintenance.

Further, these guarantees are routinely re-emphasized in case law thus creating a strong precedent for continued existence. In Lesotho, for example, the constitutional court in Leaba Thetsanev. The Prime Minister held against attempts by a Prime Minister to dismiss the Director of Prosecution. ${ }^{130}$ The court found that there was no provision in the Constitution of Lesotho empowered the Prime Minister to so act.131 Thus "under the rule of law and legality, all executive action or decision regardless of good motive or good intention must always be within the parameters of the law." ${ }^{132}$ It held that: Reinforcing this opinion, the court of appeal held that such directive was "clearly unconstitutional." 133 In this case, conflict over the appropriate relationship between the PM and DPP is easily resolved by legal interpretation though constitutional supremacy rather than discretions and will of political actors. In the South African case of the EFFv National Speaker \& Others the court held that constitutionalization of ACAs appreciate the sensitivity and the role of the agency, in the light of "the kind of complaints, institutions and personalities likely to be investigated." 134 ACAs carry the mandate to uphold the ideals of democracy by overseeing the accountability of public bodies and preventing arbitrary use of public resources. Thus, to function effectively, these bodies must be granted unfettered independence which can only be guaranteed

128 EFFv Speaker of the National Assembly \& Ors (2016).

129 See sections 134 and 140 of the Constitution.

130 Thetsane \& Others $v$ The Prime Minister \&Others (2014) LSHC 21.

131 Thetsane \& Others $v$ The Prime Minister \&Others (2014) LSHC 21.

132 Thetsane \& Others $v$ The Prime Minister \&Others (2014) LSHC 21.

133 See Thetsane \& Others $v$ The Prime Minister \& Others (2014) LSCA 53.

134 Economic Freedom Fighters $v$ Speaker of the National Assembly and Others (2016). 
by constitutional supremacy. ${ }^{135}$ As is evident in many countries, political commitment or integrity does not always drive anti-corruption efforts.

\section{Bibliography}

Afrobarometer (2008), Neither Consolidating nor Fully Democratic: The Evolution of African Political Regimes, 1999-2008. Accessed December 26, 2019 http:// afrobarometer.org/publications/bp67-neither-consolidating-nor-fullydemocratic-evolution-african-political-regimesio.

Bond, P., and G. Dor. "Neoliberalism and Poverty Reduction Strategies in Africa. Discussion paper." Regional Network for Equity in Health in Southern Africa (2003).

Botswana, Corruption and Economic Crimes Act (CECA) 1994, accessed June 5, 2019 at http://www.bankofbotswana.bw/assets/uploaded/Corruption\%2Oand\%2O Economic\%2oCrime\%2oAct.pdf.

Bratton, Michael and E. Gyimah Boadi Do Trustworthy Institutions Matter for Development? Afrobarometer Dispatch No. 112 (2016).

Bukovansky, M. "The Hollowness of Anti-Corruption Discourse" Review of International Political Economy 13, no. 2 (2006) 181-209.

Bukovansky, M. Legitimacy and Power Politics: The American and French Revolutions in International Political Culture (Princeton: Princeton University Press, 2002).

Cambridge Online Dictionary available at http://dictionary.cambridge.org/dictionary/ english/relevance.

Carr, I. "Corruption, Legal Solutions and Limits of Law" International Journal of Law in Context 3, no. 3 (2007): 227-55.

Centre for Investigative Journalism July 2019 accessed December 26, 2019 https://lescij. org/2019/o7/o3/how-wool-and-mohair-farmers-were-tossed-into-poverty/.

Christensen, T., P. Lægreid, and K. Rovik Organization Theory and the Public Sector Instrument, Culture and Myth. (London: Routledge, 2007).

Daka, D. D. "Challenges to the Successful Implementation of Anti-Corruption Measures: The Case of Political Corruption in Malawi." LLM Thesis, University of the Western Cape. (2011) accessed June 15, 2019 http://etd.uwc.ac.za/xmlui/ bitstream/handle/11394/3275/DAKA_LLM_2013.pdf?sequence=1.

De Maria, W. Cross Cultural Trespass: Assessing African Anti-Corruption Capacity International Journal of Cross Cultural Management 8, no. 3 (2008): 317-41.

De Sousa, L. "Anti-Corruption Agencies: Between Empowerment and Irrelevance", Working Paper European University Institute, Robert Schuman Centre for Advanced Studies (2009).

Doig, A. "Good Government and Sustainable Anti-Corruption Strategies: a Role for Independent Anti-Corruption Agencies?" Public Administration and Development 15 (1995): 151-65.

135 See C. Malena (2009) From Political Won't to Political Will: Building Support for Participatory Governance (Sterling, VA: Kumarian Press, 2009): 22. 
Doig, A. "Anti-Corruption Bodies as Discourse-Controlling Instruments: Experiences from South East Europe" in Governments, NGOs and Anti-corruption: The New Integrity Warriors. eds. L. De Sousa, P. Larmour, and B. Hindess. (London: Routledge, 2009).

Doig, A, D. Watt and R. Williams Measuring 'Success' in Five African Anti-Corruption Commissions: The Cases of Ghana, Malawi, Tanzania, Uganda \& Zambia. U 4 Publication, Bergen (2005).

EFFv. Speaker of the National Assembly \& Others; DAv. Speaker of the National Assembly, 2011(11). Accessed June 15, 2019 http://www.saflii.org/za/cases/ZACC/2016/11.html.

Ekeh, P. "Colonialism and the Two Publics in Africa: A Theoretical Statement" Comparative Studies in Society and History, 17, no. 1 (1975): 91-112.

Finnemore, M, and J. Sikkink. International Norms Dynamic and Political Change 52, no. 4, (1998): 887-917.

Freedom House. Freedom in the World: Democracy in Crisis (2019). Accessed June 14, 2019 https://freedomhouse.org/report/freedom-world/freedom-world-2019/ democracy-in-retreat.

Gana, A. T. "The Future of the State." International Political Science Review 6, no. 1 (1985): $115^{-32 .}$

Glenisterv. The President of the Republic of South Africa \& Others, 2011(3) SA 347 (CC). Accessed June 15, 2019 http://www.saflii.org/za/cases/ZACC/2011/6.html.

Gorta, A. Corruption Prevention: Researching How And Where To Intervene Paper Presented At Empowering Anti-Corruption Agencies: Defying Institutional Failure And Strengthening Preventive And Repressive Capacities ISCTE Lisbon, May 2008. Accessed August 10, 2016 http://ancorage-net.transparencia.pt/wp-content/ themes/twentyfourteen/assets/documentos/gorta.pdf.

Gumede, W. "Why Fighting Corruption in Africa Fails" Policy Brief: Democracy Works Foundation 14 (2013).

Heidhues, F., and G. Obare. "Lessons from Structural Adjustment Programs and their effects in Africa" Quarterly Journal of International Agriculture 50 (2011):55-64.

Heilbrunn, J. R.Anti-Corruption Agencies, Panacea or Real Medicine? (Washington, D. C.: The International Bank for Reconstruction and Development) (2005).

Klitgaard, R. Controlling Corruption (Los Angeles: University of California Press, 1998).

Lawal, G "Corruption and Development in Africa: Challenges for Political and Economic Change" Humanity \& Social Sciences Journal 2, no. 1 (2007).

Lesotho Constitution Act No. 1 of 1993. Accessed December 26, 2019 https://lesotholii. org/ls/legislation/num-act/1993/1.

Lesotho, Prevention of Corruption and Economic Offences Act 5 Amendment Act 63 of 2006. Accessed June 5, 2019 https://lesotholii.org/ls/legislation/num-act/2006/8.

Lesotho, Prevention of Corruption and Economic OffencesAct 5 of 1999. Accessed June 15, 2019 https://lesotholii.org/ls/legislation/num-act/1999/5.

MacDonald, Ronald, and T. Majeed, "Corruption and Financial Intermediation in a Panel of Regions: Cross-Border Effects of Corruption," SIRE Discussion Papers 2011-67, Scottish Institute for Research in Economics (SIRE) (2011). 
Machobane, L. A. Microscopic View into Lesotho's Forty Year Period of Independence:1966-2006 (2006) Accessed July 15, 2019 http://unpan1.un.org/ intradoc/groups/public/documents/aapam/unpano25648.pdf.

Mafeje, A. The Role of State Capitalism in Predominantly Agrarian Economies." Science, Ideology and Development, Three essays on Development (Upsala: The Scandinavian Institute of African Studies, 1978): 14-45.

Malawi, Corrupt Practices Act no. 18 of 1995 Accessed December 26, 2019 https:// malawilii.org/mw/consolidated_legislation/704.

Malephane, L. "Election Fatigue? Half of Basotho want a Different Way to Choose Leaders" Afrobarometer Dispatch no. 309 (2019).

Malephane, L. "Declining Trust: Basotho Perceptions of Government Corruption and Performance Drive Drop in Popular Trust" Afrobarometer Policy Paper no. 57 (2019).

March, J., and J. Olsen Democratic Governance. (New York: Free Press, 1995).

March, J., and J. Olsen "The Logic of Appropriateness" WP o4/og Centre for European Studies. (2009) Accessed June 12, 2019 https://www.sv.uio.no/arena/english/ research/publications/arena-working-papers/2001-2010/2004/wpo4_9.pdf.

Malena, C. From Political Won't to Political Will: Building Support for Participatory Governance. (Sterling, VA: Kumarian Press, 2009).

Mauritius, Prevention of Corruption Act no. 5 of 2003 Accessed May 15, 2019 https:// www.icac.mu/the-prevention-of-corruption-act-2002/.

Mbaku, J. M. Corruption in Africa: Causes, Consequences and Cleanups (Plymouth: Lexington Books, 2007).

McCoy, J. and H. Heckel "The Emergence of a Global Anti-Corruption Norm" International Politics 38 (2001): 65-9o.

Meagher, P. "Anti-Corruption Agencies: A Review of Experience” Journal of Economic Policy Reform 8, no. 1 (2005): 69-103.

Mills, A. Causes of Corruption in Public Sector Institutions and its Impact on Development: Turning what we know into what we do. (article prepared in the scope of Expert Group Meeting on 'Preventing Corruption in Public Administration: Citizen Engagement for Improved Transparency and Accountability' United Nations, New York, 2012) Accessed December 26, 2019 http://unpan1.un.org/intradoc/groups/ public/documents/un-dpadm/unpano49589.pdf.

Mo Ibrahim Institute, Index of African Governance (2018) Accessed June 14, 2019 http:// mo.ibrahim.foundation/iiag.

Monyake, M., and D. Hough "Citizens, Bribery and the Propensity to Protest," Commonwealth \& Comparative Politics 57, no. 3 (2019): 282-302.

Mothibe, T. "Political Parties and Political Instability in Lesotho" in Towards an Anatomy of Persistent Political Instability in Lesotho 1966-2016 eds. M. Thabane (Roma: National University of Lesotho, 2017): 23-46.

'Nyane, H. "The Advent of Coalition Political and the Crisis of Constitutionalism in Lesotho" in Towards an Anatomy of Persistent Political Instability in Lesotho 19662016 eds. M. Thabane (Roma: National University of Lesotho, 2017): 75-100 
Ocheje, P. D. "When Law Fails: A Theory of Self Enforcing Anti-Corruption Legislation in Africa" The Law and Development Review 4, no. 3 (2011): 238-80.

OSISA, Effectiveness of Anti-Corruption Agencies in Southern Africa, (Johannesburg: Open Society Initiative for Southern Africa, 2017).

OECD "Specialised Anti-Corruption Institutions: Review of Models" (2008) Accessed June 15, 2019 http://www.oecd.org/corruption/acn/39971975.pdf.

Polzer, T. "Corruption: Deconstructing the World Bank Discourse" Working Paper Series, Development Studies Institute no. o1-18 (2001).

Pope, Jeremy TI Source Book 200o. Confronting Corruption: The Elements of a National Integrity System (Berlin: Transparency International, 2000).

Poulter, S Legal Dualism in Lesotho: A Study of the Choice of Law Question in Family Matters. (Morija: Morija Sesuto Book Depot, 1979).

Quah, J. S. T. "Comparing Anti-Corruption Measures in Asian Countries: Lessons to be Learnt" Asian Review of Public Administration 11, no. 2, (1999): 71-9o.

Rakolobe, M "Politicised Public Service and Corruption in Lesotho" Strategic Review for Southern Africa 41, no. 1 (2019).

Ramkalawon v. State 2012 SCJ 254 in Mujui, J. "Strengthening Democracy Through Investigating, Prosecuting and Punishing Corruption in Mauritius" East African Journal of Peace \& Human Rights 21, no. 2 (2015): 282-326.

Rose-Ackerman, S. "Foreign Direct Investment and the Business Environment in Developing Countries: The Impact of Bilateral Investment Treaties” Paper no. 293 Yale Law \& Economic Research (2005).

Satgar, V. "Beyond Marikana: The Post-Apartheid South Africa State" Africa Spectrum $47(2012): 33-62$.

Scott, I "The Challenge of Preserving Hong Kong's Successful Anti-Corruption System” Asian Education and Development Studies 6, no. 3, (2016): 227-37.

Setai, B. "Structural Adjustment Program in Lesotho" Africa Development / Afrique et Développement 16, no. 1 (1991): $5^{-22 .}$

Shah, A (2007) "Tailoring the Fight against Corruption to Country Circumstances" Chapter 7 in Shah, A.Performance Accountability and Combating Corruption (Washington, DC.: World Bank): 229-47 Accessed June 15, 2019 http://www. worldbank.org/en/news/press-release/2013/12/19/corruption-developingcountries-world-bank-group-president-kim.

South Africa, Prevention and Combating of Corrupt Activities Act no. 12 of 2004 Accessed May 15, 2019 http://www.justice.gov.za/legislation/acts/2004-012.pdf.

Stiglitz, J. Globalization and Its Discontents. (London: Penguin Books, 2002).

Swaziland Prevention of Corruption Amendment Act, 1 of 1997. Accessed June 7, 2019 http://www.laga-enforcement.org/Portals/o/Documents/Legal\%2odocuments/ Africa\%2oanti-corruption/Swaziland_Prevention\%20of\%2oCorruption\%2O Amendment\%2oAct.pdf.

Swaziland Prevention of Corruption Order No. 19 of 1993. Accessed December 26, 2019 http://www.track.unodc.org/LegalLibrary/LegalResources/Swaziland/Laws/ Prevention\%2oof\%2oCorruption\%2oOrder\%2oNo.\%2o19\%2o(1993).pdf. 
Thabane, M. “Towards an Identification of Historical Roots of Lesotho's Political Instability”. Towards an Anatomy of Persistent Political Instability in Lesotho 19662016 (Roma: National University of Lesotho, 2017): 1-22.

Thetsane v. Prime Minister and Others (2014) LSCA 53 Accessed December 26, 2019 https://lesotholii.org/node/3405.

World Bank Helping Countries Combat Corruption: The Role of the World Bank, (Washington, D. C.: The World Bank, 1997).

\section{vin}

Thato Toeba is an LLD Candidate at the University of the Western Cape, South Africa. 